\title{
Anti-Inflammatory Activity of Combined Aerodisperse System in the Conditions of Experimental Cervical Lymphadenite
}

\author{
Khadzieva Zahra Dzamaleevna', Aleynikova Nelly Segeevna', Pozdnyakov Dmitry Igorevich ${ }^{2}$, Rybalko Anastasiya Evgenievna ${ }^{1}$ \\ 'Department of Pharmaceutical Technology with course Medical biothechnology Pyatigorsk Medical and Pharmaceutical Institute, RUSSIA. \\ 2Department of Pharmaology with course of clinical Pharmaology Pyatigorsk Medical and Pharmaceutical Institute, RUSSIA.
}

\begin{abstract}
Objective: The aim of this study was to assess the presence of an antiinflammatory activity of a new combined aerodisperse system under conditions experimental lymphadenite. Materials and Methods: Lymphadenite was reproduced by injection of bacterial lipopolysaccharide into the lymph node. The test spray and comparison spray (Tantum Verde $®$ ) were introduced by the irrigation of the posterior pharyngeal wall for 3 days after the induction of inflammation in doses: $0.5 \mathrm{mg} / \mathrm{kg} ; 1 \mathrm{mg} / \mathrm{kg} ; 1.5 \mathrm{mg} / \mathrm{kg}$, $2 \mathrm{mg} / \mathrm{kg}$. After this time estimate the concentration of CRP, TNF- $\alpha$, leukocytes in the blood and the severity of the inflammatory edema of the lymph node. Results: test spray (all doses) provide reduce the concentration of CRP, TNF- $\alpha$ and leukocytes in the blood, and in doses of $0.5 \mathrm{mg} / \mathrm{kg}$ and $1 \mathrm{mg} / \mathrm{kg}$ - inflammatory edema of the lymph nodes by $12.9 \%(p<0.05)$ and $9.3 \%(p<0.05)$, respectively. In this case, the anti-inflammatory effect of the test spray in doses of $1 \mathrm{mg} / \mathrm{kg}$ is comparable to that of benzidamine. Conclusion: The test spray has an anti-inflammatory effect
\end{abstract}

comparable to the pharmacological effect with the benzidamine, and may be included in further development, with the goal of creating a drug for the treatment of URT diseases. Since the increase in the dose of the test spray does not increase the pharmacological activity, the optimal dose of the test spray can be considered $1 \mathrm{mg}$, which is equivalent to 2 sprayings.

Key words: Inflammation, Respiratory tract, Eucalyptus, Sage.

\section{Correspondence}

Pozdnyakov Dmitry Igorevich, Pyatigorsk Medical and Pharmaceutical Institute a branch Volgograd State Medical University, Pyatigorsk, (357532, Pyatigorsk, av. Kalinina 11). RUSSIA.

Phone: +7-918- 756- 08- 89

Email: pozdniackow.dmitry@yandex.ru

DOI: 10.5530/jyp.2018.10.66

\section{INTRODUCTION}

To date, acute and chronic diseases of the upper respiratory tract (URT) represent one of the significant problems of otorhinolaryngology. ${ }^{1}$ According to WHO statistics, 15 to $36 \%$ of the adult population in one form or another suffer from this nosology every year in the world. ${ }^{2}$ URT disease is diagnosed almost throughout the calendar year, but in the period from September to April, they acquire a massive nature, which is associated with an inadequate reactivity of the immune system and an increased tendency to infection with the URT mucosa. The most common diseases of the upper respiratory tract are considered to be rhinitis, sinusitis, adenoiditis, tonsillitis, laryngitis and pharyngitis, in which various parts of the respiratory tract are affected. ${ }^{2}$ In this case, the generic pathogenetic mechanism of damage to the mucosa of the URT under the conditions of initiation of the pathological processes presented is the induction of inflammation. Thus, it can be assumed that anti-inflammatory therapy can rightfully be considered line of URT treatment. ${ }^{3}$ Experimental and clinical studies of recent years show that without proper pharmacotherapeutic impacts, which limits the focus of the inflammatory reaction, one can only talk about the success of the treatment measures, which in turn dictates the direction of searching for new drugs for the treatment of URT diseases - anti-inflammatory drugs. According to the clinical studies, in the conditions of inflammatory diseases of the URT, preference should be given to drugs acting locally, as well as providing a complex (anti-inflammatory, local anesthetic and antibacterial) action that prevents the risk of systemic side effects, and also reduces the likelihood of chronic disease and increases, thereby, the effectiveness of ongoing pharmacotherapy. ${ }^{4}$ The use of steroidal and non-steroidal anti-inflammatory drugs for the treatment of inflammation is associated with a high risk of developing unwanted reactions, ${ }^{5}$ which determines the search for alternative medicines among natural objects that can combine high efficacy and safety of use. ${ }^{6}$

\section{MATERIALS AND METHODS}

\section{Design of the experiment}

The content and all manipulations conducted with animals corresponded to the norms of international experimental ethics (European Convention for the Protection of Vertebrates used for experiments and other scientific purposes (Strasbourg, 1986). The experiment was performed on 42 Wistar line rats-male, divided into 7 equal groups of 6 individuals in each. The first group is pseudo-operated animals (PO). The second group of rats is a group of negative control animals (NC), with reproduced lymphadenite without pharmacological support. The third group of rats - with reproduced lymphadenite - received a comparison drug benzidamine (spray Tantum Verde ${ }^{\oplus}$, Angelini, Italy) at a dose of $1.2 \mathrm{mg}$ (1 spraying). ${ }^{3}$ The fourth, fifth, sixth and seventh groups of animals with reproduced lymphadenite received the test spray (chlorhexidine + Eucalyptus globulus extract + Salvia officinalis leaf extract) at doses of $0.5 \mathrm{mg}$ (1 spraying), $1 \mathrm{mg}$ (2 spraying), $1.5 \mathrm{mg}$ (3 spraying) and $2 \mathrm{mg}$ (4 spraying), respectively. The test spray and spray of comparison were introduced by irrigation of the posterior pharyngeal wall of experimental animals for 3 days after the induction of inflammation. 


\section{Model of acute lymphadenite}

The narcotized animals (chloral hydrate, $350 \mathrm{mg} / \mathrm{kg}$ ) were fixed on the operating table in the back-down position. In the area of the neck anterior surface, hair removal was performed; antiseptic treatment of the operating field was performed. Then a midline incision of the skin was performed, and fascias were excised with tweezers, exposing the lymph node (Figure 1). The pro-inflammatory LPS (E. coli, Sigma-Aldrich) was administered in a volume of $20 \mu \mathrm{l}$ at a rate of $0.1 \mathrm{mg} / \mathrm{kg}$. The wound was layer-by-layer sutured, antiseptic treatment of the joints was performed. Exposure time was $72 \mathrm{~h}$. At the end of this time, the animals were seized blood, followed by the production of serum and the determination of markers of the intensity of the inflammatory reaction - C-reactive protein (CRP) and tumor necrosis factor- $\alpha$ (TNF- $\alpha$ ). Also, the intensity of the inflammatory edema and the change in the concentration of leukocytes in the blood were assessed.

\section{Enzyme-linked immunosorbent assay}

The content of CRP and TNF- $\alpha$ was determined by the method of solidphase enzyme-linked immunosorbent assay, using species-specific sets for ELISA from Cloud Clone corp. (USA) and Infinite F50 microplate reader system (Tecan, Austria).

\section{Assessment of inflammatory edema}

The severity of the inflammatory edema was determined by the drying method, for which the lymph node was removed, weighed and dried in a dryer until a constant weight was reached at a temperature of $600^{\circ} \mathrm{C}$. Lymph node was re-weighed. The severity of edema was judged by the loss of moisture (expressed as a percentage of the initial mass of the lymph node).

\section{Determination of the content of leukocytes in the blood}

The white blood cell count (WBC) was assessed using a system of the veterinary automatic hematological analyzer BC-2400 vet (Mindray).

\section{Statistical methods}

The results of the experiments were processed using the variational statistics method using the STATISTICA 6.0 application software package (StatSoft, Inc., USA). Data were expressed as $\mathrm{M} \pm \mathrm{SE}$, tested for normal distribution using the Shapiro-Wilk test. In the case of a normal distribution of data, the Student's t-test was used to compare the averages. With an abnormal distribution of experimental results, further statistical processing of the data was carried out using the Mann-Whitney $U$ test. Differences were considered statistically significant at $\mathrm{p}<0.05$.

\section{RESULTS}

In the group of pseudo-operated rats, the total leukocyte count in the blood was $4.87 \pm 0.479 * 109$ cells / L (Table 1 ). The serum concentration of C-reactive protein and TNF- $\alpha$ (Table 1) in the PO group of rats was
$1.28 \pm 0.095 \mathrm{mg} / \mathrm{L}$ and $20.27 \pm 1.398 \mathrm{pg} / \mathrm{ml}$, respectively. The degree of hydration of the lymph node (Table 1, Figure 2) of the untreated animals was $74.26 \pm 0.296 \%$.

In the NC group of rats under acute lymphadenite, an intensification of the inflammatory process was observed, which was reflected in an increase in the concentration of CRP and TNF- $\alpha$ (Table 1) in this group of animals compared with the PO group of rats by 14.2 times $(\mathrm{p}<0.05)$ and in $10,8(\mathrm{p}<0.05)$ times, respectively. Also, in the NC group of rats, the total leukocyte count in blood increased 4.13 times $(\mathrm{p}<0.05)$ in comparison with untreated animals, and the degree of hydration of the lymph node exceeded the PO group animals by $8.9 \%(\mathrm{p}<0.05)$.

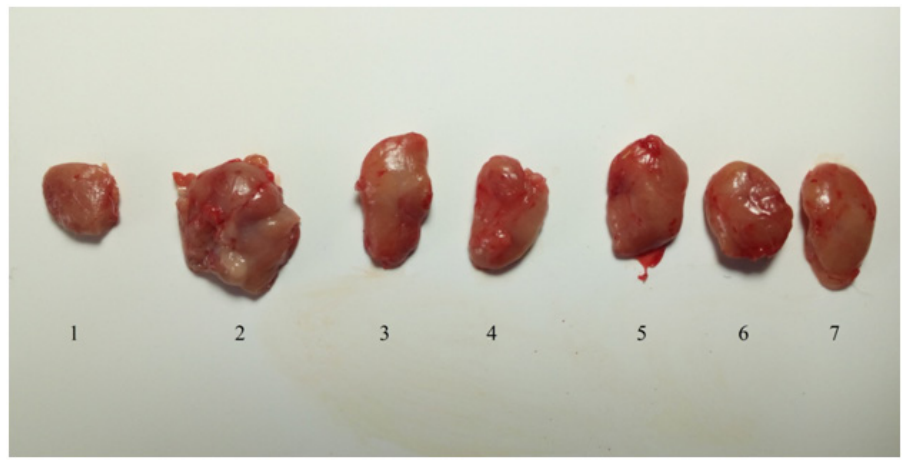

Figure 2: Visual assessment of the degree of hydration of lymph nodes in rats under experimental lymphadenite Note: 1 -lymph node of the PO group of rats; 2-lymph node of the NC group of rats; 3-lymph node of a group of animals treated with benzidamine; 4,5,6,7 - lymph nodes of rats receiving the test spray in concentrations of $0.5 \mathrm{mg} ; 1 \mathrm{mg} ; 1.5 \mathrm{mg}$ and $2 \mathrm{mg}$, respectively.

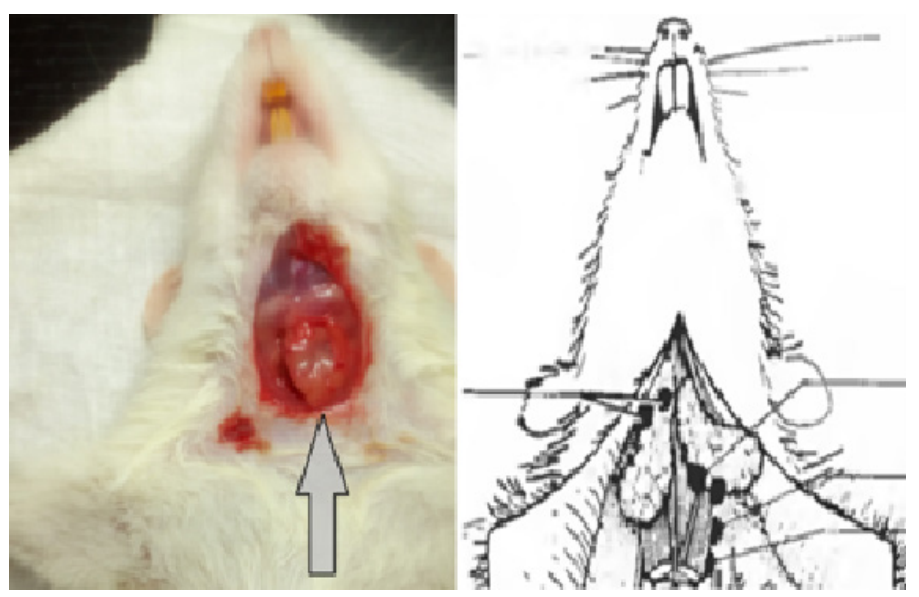

Figure 1: Administration of the proinflammatory agent.

Table 1: Change in the concentration of inflammatory markers against the background of acute lymphadenite correction by the test spray

\begin{tabular}{cccccccc}
\hline Group & PO & NC & Benzydamine & $0,5 \mathrm{mg} / \mathbf{k g}$ & $1 \mathrm{mg} / \mathrm{kg}$ & $1,5 \mathrm{mg} / \mathrm{kg}$ & $2 \mathrm{mg} / \mathrm{kg}$ \\
\hline WBC, 109 cells/L & $4,87 \pm 0,479$ & $20,13 \pm 1,112 \#$ & $15,42 \pm 0,92^{*}$ & $16,4 \pm 1,282^{*}$ & $12,78 \pm 0,8^{*}$ & $12,22 \pm 1,509^{*}$ & $13,77 \pm 1,791^{*}$ \\
Severity of edema, $\%$ & $74,26 \pm 0,296$ & $80,87 \pm 0,382 \#$ & $76,23 \pm 0,931^{*}$ & $71,59 \pm 1,962^{*}$ & $73,97 \pm 0,614^{*}$ & $79,57 \pm 0,708$ & $79,88 \pm 0,599$ \\
CRP, $\mathrm{mg} / \mathrm{l}$ & $1,28 \pm 0,095$ & $18,23 \pm 1,817 \#$ & $12,65 \pm 0,972^{*}$ & $12,73 \pm 0,731^{*}$ & $11,53 \pm 0,985^{*}$ & $11,25 \pm 1,177^{*}$ & $12,22 \pm 0,998^{*}$ \\
TNF- $\alpha, \mathrm{pg} / \mathrm{ml}$ & $20,27 \pm 1,398$ & $218,28 \pm 5,679 \#$ & $152,06 \pm 8,426^{*}$ & $150,83 \pm 15,172^{*}$ & $169,89 \pm 5,637^{*}$ & $171,57 \pm 4,746^{*}$ & $164,55 \pm 9,159^{*}$ \\
\hline
\end{tabular}

Note: \# - statistically significant relative to the PO group of rats ( $\mathrm{p}<0.05$, Mann-Whitney U-test);

* - statistically significant relative to the NC group of rats ( $\mathrm{p}<0.05$ Mann-Whitney U-test). 
In rats against the background of correction of acute lymphadenite with benzidamine in comparison with the NC group of animals, the concentration of CRP and TNF- $\alpha$ decreased (Table 1$)$ by $44.1 \%(\mathrm{p}<0.05)$ and $43.5 \%(\mathrm{p}<0.05)$, respectively. The number of leukocytes in the blood of this group of animals (benzidamine) was lower than in the NC group of rats by $30.5 \%(\mathrm{p}<0.05)$. The severity of inflammatory edema in rats against benzydamine therapy decreased by $6.1 \%$ in comparison with the group of negative control rats $(\mathrm{p}<0.05)$.

The manifestation of acute lymphadenite in rats receiving the test spray (in all the doses assessed) was less pronounced in comparison with the NC group of animals. So the concentration of CRP when applying the test spray in a dose of $0.5 \mathrm{mg} ; 1 \mathrm{mg} ; 1.5 \mathrm{mg}$ and $2 \mathrm{mg}$ decreased by $43.2 \%(\mathrm{p}<0.05) ; 58.1 \%(\mathrm{p}<0.05) ; 62 \%(\mathrm{p}<0.05)$ and $49.2 \%(\mathrm{p}<0.05)$, respectively. The content of TNF- $\alpha$ also tended to decrease (this indicator decreased by $44.7 \%(\mathrm{p}<0.05), 28.5 \%(\mathrm{p}<0.05), 27.2 \%(\mathrm{p}<0.05)$, and $32.7 \%(\mathrm{p}<0.05)$ with the spray used in doses of $0.5 \mathrm{mg}, 1 \mathrm{mg}, 1.5 \mathrm{mg}$ and $2 \mathrm{mg}$, respectively). The total number of leukocytes in the blood during application of the test spray in a dose of $0.5 \mathrm{mg}$ decreased by $22.7 \%$ $(\mathrm{p}<0.05)$, when the test spray was applied in doses of $1 \mathrm{mg} ; 1.5 \mathrm{mg}$ and $2 \mathrm{mg}$ this indicator decreased by $57.5 \%(\mathrm{p}<0.05) ; 64.3 \%(\mathrm{p}<0.05)$ and $46.2 \%(\mathrm{p}<0.05)$, respectively.

The degree of hydration of the lymph node in the application of the spray under study at doses of $0.5 \mathrm{mg}$ and $1 \mathrm{mg}$ did not statistically significantly differ from that of the PO group of rats. At the same time, the application of the test spray in doses of $1.5 \mathrm{mg}$ and $2 \mathrm{mg}$ had no significant effect on the severity of the inflammatory edema of the lymph node (no statistically significant differences were found in comparison with the NC group of rats).

\section{DISCUSSION}

Infections of the upper respiratory tract are the most common form of the infectious process in all age categories, with the inflammation dominating the pathogenesis of the upper respiratory tract infection. Inflammatory diseases of the upper respiratory tract are one of the most socially significant nosologies, significantly affecting the quality of life of people. Particularly acute problem of therapy of this group of diseases is in childhood, which is associated with high frequency and recurrence of morbidity. The inflammatory process in the airways causes increased vascular permeability and extravasation of essential nutrients. Inflammation of the epithelium of the respiratory tract is the «entrance gate» for the attachment of a secondary infection. Thus, inflammation of the upper respiratory tract, of course, requires correction. ${ }^{7}$

Currently, in the treatment of inflammatory diseases of the upper respiratory tract, a complex approach firmly presupposes the use of drugs that provide combined anesthetic, anti-inflammatory, mucolytic and antimicrobic effects, which simultaneously affects the maximum number of etiologies and symptoms. At the same time, local application of medicines comes first, allowing localizing their pharmacotherapeutic effect and reducing the incidence of side effects.

Use in acute bacterial rhinosinusitis antibiotic preparations in the form of a spray significantly increases the effectiveness of therapy and reduces the risk of complications and can be recommended in children under 1 year of age. ${ }^{8}$

Modern local therapy for acute sinusitis is directed, among other things, to reducing the contamination of the mucosa by pathogenic flora. ${ }^{9}$ Included in the composition of sprays phytocomponents (primarily essential oils) have a pronounced bactericidal, antiviral and anti-inflammatory effect, which leads to a decrease in the concentration of viruses, bacteria on the mucous membranes of the respiratory tract, improve the outflow and release from pathological contents of the paranasal sinuses, eliminate cough caused by flowing mucus down the back wall of the pharynx, restoration of the function of mucociliary transport, increasing the effectiveness of the use of topical medicines. In the surgical treatment of sinusitis in the postoperative period, complex therapy is applied, including local antiseptics, steroids and saline solutions. ${ }^{10}$

Treatment of adenoiditis surgically (removal of the tonsils) is now moving aside in connection with the important role of pharyngeal lymphoid tissue in the formation of immunological defense of the body, with priority shifting towards local drug therapy. According to bacteriological and mycological studies it was shown that the use of topical preparations with antibacterial component is adequate in $75.5 \%$ of cases of acute adenoiditis. For example, in children with adenoiditis, the expediency of using a spray for local application "Deflju-Silver" on the basis of colloidal silver, Icelandic moss and dexpanthenol with vitamins $\mathrm{A}$ and $\mathrm{E}$ is shown. The common symptom of acute inflammatory diseases of the oropharynx is, first of all, pain syndrome (sore throat) - one of the most common symptoms of upper respiratory tract diseases, which many patients consider the main problem. Thus, the symptomatic treatment of pharyngitis consists in the treatment with moisturizers and reducing irritation of the pharyngeal mucosa, as well as bactericidal therapy. The use of combined topical preparations with antiseptic and analgesic effect in the form of various dosage forms (rinsing solutions, sprays, drops, tablets, lozenges) is pathogenetically grounded.11

To stop the pain syndrome, local preparations in the form of sprays that exert anti-inflammatory, as well as disinfectant and softening effects are widely used. According to the questionnaire, in the treatment of sore throat, sprays are preferred by $88.5 \%$ of patients, most often using local antiseptic drugs. More than half (60.4\%) of respondents preferred phytopreparations, considering their use as the most effective and safe method of treatment. ${ }^{12}$

Local therapy of acute pharyngitis includes treatment of the oral cavity and pharynx with antiseptic solutions or antiseptic sprays, including plant origin (infusions, extracts, etc.). In the treatment of chronic pharyngitis, the removal of a pain symptom can be carried out by irrigation of the pharynx with symptomatic analgesic agents, and as anti-inflammatory agents, use infusions of chamomile, sage. ${ }^{13}$

In complex therapy of these pathologies often include local antimicrobial agents of a wide spectrum. The medications used in this case may include one or more antiseptic agents, including natural antiseptics (beekeeping products or plant extracts). The most convenient is the aerosol form, which allows the drug composition to be delivered directly to the inflammatory focus. It is shown that the effectiveness of irrigation of the pharyngeal mucosa with a spray with plant extracts is comparable to that of an aerosol containing a synthetic antiseptic hexetidine, but a broader spectrum of action of plant components promoted a more rapid recovery of the normal microflora of the pharyngeal mucosa. The reparative and anti-inflammatory effect of a spray containing thick extracts of the roots of licorice and eucalyptus leaves. ${ }^{14}$ is shown.

According to the data of the pharmacoepidemiological study, $74 \%$ of respondents with throat pain (pharyngitis or tonsillitis) chose the drug on their own, the most preferred dosage form being sprays. ${ }^{15}$

Since the treatment of inflammatory syndrome accompanying infectious diseases of the upper respiratory tract, it is advisable to use preparations based on plant objects in our study, we adhered to this principle.

It is also known that drugs obtained from the Eucalyptus globulus have anti-inflammatory, antiseptic and analgesic effects. ${ }^{16}$ by suppressing the main signaling pathways providing induction and maintenance of the inflammatory process, such as TLR $-4 \rightarrow \mathrm{MAPK} \rightarrow \mathrm{TNF} \rightarrow \mathrm{NFkB}$ pathway. At the same time, the use of Salvia officinalis as a basis for the creation of anti-inflammatory agents of raw materials and galenic preparations 
suppresses the formation of E-selectin, ${ }^{17}$ which prevents leukocyte infiltration of bronchopulmonary epithelium, reducing its damage. ${ }^{18}$

Thus, the plant components included in the studied aerodisperse system provide the potentiation of the anti-inflammatory effect, and the inclusion of chlorhexidine in the composition will enhance their antiseptic effect, which, however, requires further study.

\section{CONCLUSION}

The developed aerodisperse system dose-dependently reduces the severity of the inflammatory response in conditions of acute cervical lymphadenite in rats. The use of the investigated aerodisperse system at a dose of $0.5 \mathrm{mg}$ contributed to a decrease in the concentration of CRP and TNF- $\alpha$, the degree of hydration of the lymph node and leukocytosis. At a dose of $1.5 \mathrm{mg}$ and $2 \mathrm{mg}$, the application of the test spray contributed to a decrease in the concentration of leukocytes, the content of CRP and TNF - $\alpha$, but did not have a significant effect on the degree of hydration of the lymph node. The use of a spray at a dose of $1 \mathrm{mg}$ contributed to the normalization of all studied indices practically equal to the benzydamine degree. Thus, the optimal dose of the test spray can be considered a dose of $1 \mathrm{mg}$, which is equivalent to 2 spraying.

\section{ACKNOWLEDGEMENT}

This research received no specific grant from any funding agency in the public, commercial, or not-for-profit sectors.

\section{CONFLICT OF INTEREST}

The authors statement no conflict of interest with the submitted manuscript.

\section{ABBREVIATIONS}

PO: Pseudo operated; NC: Negative control Rafs; LPS: lipopolysaccharide; CRP: C Reactive Protein; TNF: Tumor Necrosis Factor.

\section{SUMMARY}

Conducted research demonstrated prospects futner study of new aerodisperse system for the therapy inflammatory diseases of upper respiratory treut

\section{REFERENCES}

1. Novikova IA, Petrenko TS. Aktivnost' perekisnogo okislenija lipidov $v$ biologicheskom materiale pacientov s recidivirujushhimi zabolevanijami verhnih dyhatel'nyh putej. Klin. Labor. d. [Clin. labor. d.].2012; 5: 22-25. [in Russian]

2. Chelenkova IN, Uteshev DB, Bunjatjan ND. Ostrye i hronicheskie vospalitel'nye zabolevanija verhnih dyhatel'nyh putej. RMJ. 2010;80(30):1878-82. [in Russian]

3. Hod'ko SV. Jeffektivnost' lekarstvennyh preparatov prirodnogo proishozhdenija v jeksperimental'nyh modeljah vospalenija verhnih dyhatel'nyh putej. S-Pb. 2015:170. [in Russian]

4. Thiebes AL, Reddemann MA, Palmer J, et al. Flexible Endoscopic Spray Application of Respiratory Epithelial Cells as Platform Technology to Apply Cells in Tubular Organs. Tiss Eng Part C, Methods. 2016;22(4):322-31.

5. Sarkar S, Mazumder S, Saha SJ, Bandyopadhyay U. Management of inflammation by natural polyphenols: A comprehensive mechanistic update. Curr Med Chem. 2016;23(16):1657-95.

6. Yadav N, Chandra H. Suppression of inflammatory and infection responses in lung macrophages by eucalyptus oil and its constituent 1,8-cineole: Role of pattern recognition receptors TREM-1 and NLRP3, the MAP kinase regulator MKP-1, and NFאB. Khan MF, ed. PLoS ONE. 2017;12(11):e0188232. doi:10.1371/ journal.pone.0188232.

7. Jesenak M, Urbancikova I, Banovcin P. Respiratory Tract Infections and the Role of Biologically Active Polysaccharides in Their Management and Prevention. Nutr. 2017;9(7):779. doi:10.3390/nu9070779.

8. Dobrecov KG. Ispol'zovanie topicheskih antibakterial'nyh preparatov pri ostrom bakterial'nom rinosinusite $u$ detej $v$ vozraste do 1 goda. Vopr sov pediatr. 2013;12(1):190-2. [in Russian]

9. Leggett JE. Acute sinusitis when - and when not - to prescribe antibiotics. Postgrad Med. 2004;115(1):13-9.

10. Kotova EN. Mestnaja terapija infekcionno-vospalitel'nyh zabolevanij rotoglotki. Vopr sov pediatr. 2012;11(5):168-70. [In Russian]

11. Radcig EJ, Zlobina NV. Topicheskie antibiotiki v lechenii ostrogo adenoidita u detej. Pediatr Zhu im. GN Speranskogo. 2015;94(5):96-100. [in Russian].

12. Gradovich $\mathrm{TI}$, Smirnova AA, Surikova OV. Farmakojepidemiologicheskij analiz lekarstvennyh preparatov, ispol'zuemyh pri lechenii boli v gorle. Bull med Ikonf. 2013;(2):389-90. [in Russian].

13. Polunina TA, Vishneva EA. Faringity u detej. Pediatr farmakol. 2011;8(5):106-8. [in Russian]

14. Voroshilina MA, Ivanova EP. Farmakojepidemiologicheskoe issledovanie potrebitel'skogo povedenija pri vybore lekarstvennyh sredstv dlja lechenija boli v gorle. Bull med I- konf. 2013;3(2):388. [in Russian].

15. Khadzhieva ZD, Zilfikarov IN, Krahmalev IN. Vybor optimal'nogo sostava kompozicii spreja Na osnove gustogo jekstrakta hlorofillipta. Nauch. ved. BGU. Serija: Med and Farm. 2010;22(2):133-6. [in Russian].

16. Silva J, Abebe W, Sousa SM, Duarte VG, Machado MI, Matos FJ. Analgesic and anti-inflammatory effects of essential oils of Eucalyptus. J Ethnopharmacol. 2003;89(2-3):277-83.

17. Vogl S, Picker P, Mihaly-Bison J, et al. Ethnopharmacological in vitro studies on Austria's folk medicine-An unexplored lore in vitro anti-inflammatory activities of 71 Austrian traditional herbal drugs. J Ethnopharmacol. 2013:149(3):750-71. doi:10.1016/j.jep.2013.06.007.

18. Laviola L, Orlando MR, Incalza MA, et al. TNF $\alpha$ Signals via p66Shc to Induce E-Selectin, Promote Leukocyte Transmigration and Enhance Permeability in Human Endothelial Cells. Ushio-Fukai M, ed. PLoS ONE. 2013:8(12):e81930. doi:10.1371/journal.pone.0081930.

Article History: Submission Date : 06-02-2018; Revised Date : 23-02-2018; Acceptance Date : 15-04-2018.

Cite this article: Khadzieva Z.D, Aleynicova N.S, Pozdnyacov D.I, Rybalko A.E.. Anti-Inflammatory Activity of Combined Aerodisperse System in the Conditions of Experimental Cervical Lymphadenite. J Young Pharm. 2018;10(3):299-302. 